\title{
Absence of HTLV-1/2 infection and dermatological diseases in Manaus, State of Amazonas, Brazil
}

\author{
Leny Nascimento da Motta Passos ${ }^{[1]}$, Márcia Poinho Encarnação de Moraes ${ }^{[1]}$, \\ Bruna Tamegão-Lopes ${ }^{[2]}$, José Alexandre Rodrigues de Lemos ${ }^{[3]}$, \\ Paulo Roberto de Lima Machado ${ }^{[4]}$, Marcelo Távora Mira ${ }^{[5]}$ and Sinésio Talhari ${ }^{[6]}$
}

\begin{abstract}
[1]. Departamento de Ensino e Pesquisa, Hematologia, Fundação Hospitalar de Hematologia e Hemoterapia do Amazonas, Manaus, AM. [2]. Departamento de Imunologia Básica e Epidemiologia Básica, Faculdade Metropolitana da Amazônia, Manaus, AM. [3]. Departamento de Laboratórios de Biologia Celular e Molecular do Hemocentro do PRA, Instituto de Ciências Biológicas, Universidade Federal do Pará, Belém, PA. [4]. Serviço de Imunologia, Universidade Federal da Bahia, Escola Baiana de Medicina e Saúde Pública. Salvador, BA. [5]. Programa de Pós-Graduação em Ciências da Saúde, Centro de Ciências Biológicas e da Saúde de Curitiba, Pontifícia Universidade Católica do Paraná, Curitiba, PR. [6]. Departamento de Dermatologia Tropical, Fundação de Medicina Tropical Heitor Dourado do Amazonas. Clínica de Dermatologia Talhari, Universidade Nilton Lins do Amazonas, Manaus, AM.
\end{abstract}

\begin{abstract}
Introduction: The prevalence of human T-cell lymphotropic virus types 1 and 2 (HTLV-1/2) infection is heterogeneous across different populations. We tested the hypothesis that HTLV-1/2 infection occurs more often in dermatological patients. Methods: A total of 1,091 patients from a tropical dermatology clinic were tested for HTLV-1/2. In parallel, 6865 first-time blood donors from the same geographic area were screened for HTLV-1/2; HTLV-1/2 positive blood donors underwent dermatological examinations. Results: The prevalence of HTLV-1/2 in first-time blood donors was $0.14 \%$. No co-occurrence of HTLV- $1 / 2$ infection and dermatological conditions was observed. Conclusions: Our results challenge the hypothesis that HTLV-1/2 infection occurs more often in dermatological patients.
\end{abstract}

Keywords: HTLV-1/2. Dermatology. Association. HTLV and skin diseases.

Human T-cell lymphotropic virus (HTLV) was first identified in 1980. It is a member of the Retroviridae family, sub-family Ortothoretroviridae ${ }^{1}$. The global distribution of HTLV is heterogeneous, with high prevalence in Japan, the Caribbean, and South and Central America, and low prevalence in the Middle East and Melanesia ${ }^{2}$. Prevalence studies, performed in blood donors, indigenous populations, and pregnant women in Brazil, suggest that there are an estimated 2 million carriers of HTLV-1/2, and that the distribution varies based on ethnicity, race, and/or population groups ${ }^{3}$. In 1997, a positive test rate for HTLV- $1 / 2$ of $0.08 \%$ was observed in 2 independent population samples of 1,200 blood donors from Manaus and Florianópolis, and a positive test rate of $1.35 \%$ was observed in 1,040 blood donors from Salvador ${ }^{4}$. In a survey of more than 6 million blood donors from 27 Brazilian urban centers, the prevalence of HTLV- $1 / 2$ ranged from $0.04 \%$ in Florianópolis to $1 \%$ in São Luis, with a national average of $0.326 \%{ }^{5}$. In Manaus, the positive test rate reached $0.53 \%$, which was much higher than was reported in 1997; however, the 2005 study did not confirm positive enzyme-linked immunosorbent assay (ELISA) test

\footnotetext{
Address to: Dr $^{\mathrm{a}}$ Leny Nascimento da Motta Passos. Hematologia/Fundação HEMOAM. Av. Constantino Nery 4397, Chapada, 69050-002 Manaus, AM, Brasil. Phone: 5592 3655-0100; Fax: 5592 3655-0167

e-mail: lenypassos.hemato@hotmail.com

Received 7 October 2013

Accepted 22 January 2014
}

results by Western Blot. In 2003, a study of 11,121 blood donor samples from the State of Acre reported that $12(0.11 \%)$ samples were positive for HTLV: $8(0.07 \%)$ samples were positive for HTLV-1, $2(0.02 \%)$ samples were positive for HTLV-2, and $2(0.02 \%)$ samples were indeterminate ${ }^{6}$.

An estimated $95 \%$ of individuals infected by HTLV remain asymptomatic; however, $2 \%$ develop adult T-cell lymphoma/ leukemia (ATLL) and 2-3\% present with HTLV-I associated myelopathy/tropical spastic paraparesis (HAM/TSP) ${ }^{7,8}$. In addition, uveitis ${ }^{9}$ is associated with HTLV-I. Dermatoses, including infective dermatitis ${ }^{10}$, neoplasia, Norwegian scabies, acquired ichthyosis, and dermatophytosis ${ }^{11}$ are associated with HTLV-I infection. These associations suggest that HTVL-I/II may be more prevalent in individuals presenting skin diseases. Interestingly, in the Brazilian State of Minas Gerais, 0.7\% of 1,229 patients at a dermatology clinic tested positive for HTLV- $1 / 2$, which is 3.3 times higher than the $0.22 \%$ positive test rate observed in 80,902 blood donors recruited from the same geographical area $(\mathrm{p}=0.006)^{12}$.

Our hypothesis is that the HTLV positivity rate is increased in individuals affected by dermatological diseases and that some of these diseases may be used as markers for HTLV infection. To test this hypothesis, HTLV-1/2 serological testing was performed in 1,091 patients presenting with different dermatological diseases at the tropical dermatology outpatient clinic of the Heitor Vieira Dourado Tropical Medicine Foundation (FMT-HVD) in Manaus, Amazonas between September 2008 and September 2009. A sample size of 1,070 individuals was estimated to have the power to achieve a $5 \%$ significance level 
with a sampling error of $0.4 \%$ and was calculated based on an expected 10,000 dermatological consultations at FMT-HVD and a prevalence of $0.5 \%$ of HTLV- $1 / 2$ in Brazil. Results were analyzed and compared to the serological records of 6,865 first-time blood donors from the Hematology and Hemotherapy Foundation of Amazonas (HEMOAM) enrolled during the same time period. A total of 15 first-time blood donors with a positive HTLV-1/2 test were identified, contacted, re-tested, and, if confirmed positive, referred for a dermatological exam. All dermatological patients and blood donors that tested positive for HTLV-1/2 provided informed consent agreeing to participate on the study, which was approved by the Research Ethics Committee of the HEMOAM (protocol number CAAE0057.0.114.000-7).

HTLV-1/2 serology was performed by quantitative, sandwich ELISA, according to the manufacturer's instructions (Abbot Murex HTLV-1/2 kit, 2006). Reactive or indeterminate samples were tested in duplicate with a second ELISA. If the positive test was confirmed, patients were invited to provide a second blood sample, and the fresh sample was tested by ELISA and for viral protein by Western Blot and viral ribonucleic acid (RNA) by quantitative reverse transcription polymerase chain reaction $(\mathrm{RT}-\mathrm{PCR})^{13}$. A questionnaire was administered at the time of enrollment in the study and included questions about gender, age, skin color, marital status, and place of origin. The characteristics of the study participants are summarized in Table 1.

In the 1,091 patients, the most commonly observed dermatoses were leishmaniasis, unspecific dermatitis, psoriasis, chronic skin ulcer, vitiligo, herpes zoster, urticaria, impetigo, leprosy, and lichen planus. None of these patients tested positive for HTLV- $1 / 2$ by ELISA. Of the 15 first-time blood donors that tested positive for HTLV-1/2 by ELISA, HTLV-1/2 positivity was confirmed by western Blot and RT-PCR in 10 blood donors, for a prevalence of HTLV-1/2 of $0.14 \%$. None of the $10 \mathrm{blood}$ donors presented with dermatological diseases.

Studies aiming to investigate the prevalence of HTLV-1/2 infection in Brazil have produced distinct results that reflect the heterogeneity of the population and the different methods of analysis. For example, in the State of Amazonas, 2 previous blood donors surveys performed in 1997 and in 2005 revealed a prevalence of HTLV- $1 / 2$ of $0.08 \%{ }^{4}$ and $0.53 \%$, respectively; however, the latter prevalence is likely an overestimation, as it was based solely on ELISA results, with no confirmation of positive data by western Blot. Our study, which examined a large population of first-time blood donors, observed a prevalence of HTLV-1/2 of $0.14 \%$, which was confirmed by 3 independent methods. This result is closer to what was observed in 1997, although it is double the prevalence observed in 1997. Any inference about a possible increase in the prevalence of HTLV$1 / 2$ in Manaus is limited by the rarity of the event and the relative small sample size of the 1997 study. However, it is reasonable to assume that the prevalence of HTLV-1/2 in Manaus has not decreased as has been observed in other locations, including Brazil and Japan ${ }^{8,14,15}$. The decreased HTLV-1/2 observation rate is likely due to increased specificity of diagnostic tests, which has led to the reduction in the proportion of false positives,
TABLE 1 - Characteristics of dermatological patients and HTLV-1/2 positive first-time blood donors.

\begin{tabular}{|c|c|c|}
\hline Variable & Patients $(1,091)$ & Blood donors (15) \\
\hline \multicolumn{3}{|l|}{ Age (years) } \\
\hline mean & 36.6 & 36.4 \\
\hline median & 34.0 & 37.0 \\
\hline standard deviation & 17.9 & 13.0 \\
\hline \multicolumn{3}{|l|}{ Gender (\%) } \\
\hline male & 51.8 & 66.7 \\
\hline female & 48.2 & 33.3 \\
\hline \multicolumn{3}{|l|}{ Skin color $(\%)$} \\
\hline white & 38.3 & 38.4 \\
\hline other & 61.7 & 61.6 \\
\hline \multicolumn{3}{|l|}{ Marital status (\%) } \\
\hline single & 52.4 & 40.0 \\
\hline married & 39.3 & 40.0 \\
\hline other & 8.3 & 20.0 \\
\hline \multicolumn{3}{|l|}{ Place of origin $(\%)$} \\
\hline Manaus & 47.0 & 67.0 \\
\hline country side & 28.0 & 0.0 \\
\hline other state & 25.0 & 33.0 \\
\hline
\end{tabular}

or a real reduction in the transmission rate of the disease in populations with better access to education and prevention initiatives administered by the public health services.

In our study, the presence of HTLV-1/2 was not detected in patients presenting at a tropical/infectious dermatology clinic, which is in contrast to previous reports of associations between HTLV-1/2 and skin diseases ${ }^{13}$. However, it is difficult to compare results obtained by studies with distinct study methodologies and on different population samples. The low prevalence of HTLV-1/2 detected in our study may reflect the localized transmission of the virus within population clusters, a behavior that must be taken into account. Despite these limitations, our finding challenges the hypothesis that HLTV-1/2 infection cooccurs more often among patients presenting dermatological conditions. In the population of Manaus, there is no correlation between HTLV-1/2 infection and dermatological conditions.

\section{ACKNOWLEDGMENTS}

The authors would like to thank the health and administrative staff of the Fundação de Hematologia e Hemoterapia do Amazonas (HEMOAM) and the Fundação de Medicina Tropical Heitor Vieira Dourado (FMT-HVD) for the valuable support provided. Of particular importance, we would like to thank all patients that agreed to participate. 


\section{CONFLICT OF INTEREST}

The authors declare that there is no conflict of interest.

\section{FINANCIAL SUPPORT}

This study was funded by the Fundação de Hematologia e Hemoterapia do Amazonas (HEMOAM).

\section{REFERENCES}

1. Poiesz BJ, Ruscetti FW, Gazdar AF, Bunn PA, Minna JD, Gallo RC. Detection and isolation of type $\mathrm{C}$ retrovirus particles from fresh and cultured lymphocytes of a patient with cutaneous T-cell lymphoma. Proc Natl Acad Sci USA 1980; 77:7415-7419.

2. Proietti FA, Carneiro-Proeitti AB, Catalan-Soares BC, Murphy EL. Global epidemiology of HTLV-I infection and associated diseases. Oncogene 2005; 24:6058-6068.

3. Carneiro-Proietti ABF, Ribas JGR, Catalan-Soares BC, Martins ML, Brito-Melo GEA, Martins-Filho OA, et al. Infecção e doença pelos vírus linfotrópicos humanos de células $\mathrm{T}$ (HTLV-I/II) no Brasil. Rev Soc Bras Med Trop 2002; 35:499-508.

4. Galvão-Castro B, Loures L, Rodrigues LG, Sereno A, Ferreira Jr OC, Franco LG, et al. Distribution ofhuman T-lymphotropic virus type I among blood donors: a nationwide Brazilian study. Transfusion 1997; 37:242-243.

5. Soares C. Heterogeneous geographic distribution of human T-cell lymphotropic viruses I and II (HTLV-I/II): serological screening prevalence rates in blood donors from large urban areas in Brazil. Cad Saude Publica 2005;21:926-931.
6. Colin DD, Alcantara LCJ, Santos FLN, Uchoa R, Tavares-Neto J. Prevalência da infecção pelo vírus linfotrópico humano de células $\mathrm{T}$ e fatores de risco associados à soropositividade em doadores de sangue da cidade de Rio Branco, AC, Brasil (1998-2001). Rev Soc Bras Med Trop 2003; 36:677-683.

7. Hollsberg P, Hafter DA. Seminars in medicine of Beth Israel Hospital, Boston. Pathogenesis of diseases induced by human lymphotropic virus type I infection. N Engl J Med 1993; 328:1173-1182.

8. Tsukasaki K. Adult T-cell leukemia-lymphoma. Hematology 2012; 17 (suppl I):32-35

9. Mochizuki M, Watanabe T, Yamaguchi K, Yoshimura K, Nakashima $\mathrm{S}$, Shirao M, et al. Uveitis associated with human T-cell lymphotropic virus type I. Am J Ophthalmol 1992; 114:123-129.

10. La Grenade L, Hanchard B, Fletcher V, Cranston B, Blattner W. Infective dermatitis of Jamaican children: a marker of HTLV-I infection. Lancet 1990; 336:1345-1347.

11. Nobre V, Guedes ACM, Proietti FA, Stanciolli E, Martins ML, Serufo JC, et al. Lesões dermatológicas em pacientes infectados pelo vírus linfotrópico humano de células T do tipo 1 (HTLV-1). Rev Soc Bras Med Trop 2005; 38:43-52.

12. Nobre V, Guedes AC, Proietti FA, Martins ML, Nassif G, Serufo JC, et al. Increased Prevalence of Human T cell lymphotropic virus type 1 in patients attending a Brasilian dermatology clinic. Intervirology 2007; 50:316-318.

13. Tamegão-Lopes BP, Rezende PR, Maradei-Pereira LAC, Lemos JAR. Carga proviral do HTLV-1 e HTLV-2: um método simples através da PCR quantitativa em tempo real. Rev Soc Bras Med Trop 2006; 39:504-506.

14. Lima GM, Eustáquio JMJ, Martins RA, Josahkian JA, Pereira GA, Morais-Souza $\mathrm{H}$, et al. Declínio da prevalência do HTLV-1/2 em doadores de sangue do hemocentro Regional da Cidade de Uberaba, Estado de Minas Gerais, 1995 a 2008. Rev Soc Bras Med Trop 2010; 43:421-424.

15. Satake M, Yamaguchi K, Tadokoro K. Current Prevalence of HTLV-1 in Japan as determined by Screening of Blood Donors. J Med Virol 2012; 84:325-335. 